\title{
Is the exchange rate an adjustment mechanism?
}

\author{
Nieves Carmona-González \\ Department of Economics, Universidad Francisco de Vitoria 28223 Pozuelo de Alarcón, Madrid (Spain) \\ e-mail:n.carmona@ufv.es
}

\section{Carmen Díaz-Roldán}

Department of Economics, Universidad de Castilla-La Mancha 13071 Ciudad Real (Spain) e-mail: carmen.diazroldan@uclm.es

Paper presented at: The 79th International Atlantic Economic Conference, Milan, Italy, March 2015

Carmen Díaz-Roldán acknowledges financial support from the Spanish Ministry of Economy and Competitiveness (Project ECO2011-29314-C02-02).

\section{Is the exchange rate an adjustment mechanism?}

The Optimal Currency Areas (OCA) theory pioneered by Mundell (The American Economic Review, 1961) arose in the early sixties of the last century as an extension of the literature on the choice between fixed or flexible exchange rates. As noticed by McKinnon (Journal of Common Market Studies, 2004) and De Grauwe (Journal of Common Market Studies, 2006), there is an apparent contradiction in Mundell's theories regarding currency unions. According to OCA theory, asymmetric shocks threaten the success of a monetary union. In the absence of full wage and price flexibility, the criteria for constituting an OCA is the existence of a high degree of production factor mobility within the area in question.

A decade later, Mundell (The Economics of Common Currencies, 1973a, 1973b) stressed that a monetary union should not be seen as costly for stabilization policy. The main cost of joining a monetary union is the loss of flexibility in macroeconomic stabilization policy when relinquishing control over exchange rate policy. In a world of 
free capital mobility and growing capital markets, followed by continuous liberalization and deregulation of capital movements, as have taken place in recent years, exchange rates have become a source of destabilization and currency crisis. Moreover, recent experiences (such as the Argentinian crisis in 1975, European Monetary System in 1992, Mexico in 1994, Southeast Asia in 1997, Russia in 1998, Argentina in 2002, Iran in 2012 and Russia in 2014) have shown the increasing difficulty countries face in building the reputation needed to sustain a fixed exchange rate system.

Countries joining a monetary union give up an adjusting mechanism (the exchange rate), but the monetary union becomes a useful economic framework eliminating exchange rate volatility as a source of asymmetric shocks. As addressed by McKinnon (Journal of Common Market Studies, 2004) Mundell (The Economics of Common Currencies, 1973a, 1973b) defended the importance of absolutely fixed exchange rates, which secure full capital market integration and prevent economies from risk sharing. Put differently, only in a monetary union are capital markets fully integrated and used as an insurance mechanism against asymmetric shocks (De Grauwe, P., Journal of Common Market Studies, 2006). Moreover, the integration of capital markets provided by a monetary union reduces risk premia, lowers the demand for international reserves and, consequently, generates a seignorage gain for countries in the area.

From a different approach, among the models of exchange rate determination, the monetary approach has been used to explain volatility occurring after implementation of the floating exchange rate system in 1973 (Wilson I., Journal of Business Inquiry, 2009). The argument is quite simple: when the supply of money increases (decreases), prices increase (decrease) and the price of foreign goods rise (decline). In other words, the exchange rate varies proportionately with the relative supply of money. Monetary policy is a source of exchange rate instability under a system of flexible exchange rates. 
Adoption of a common currency, rather than a fixed exchange rate, constitutes an alternative to avoid asymmetric disturbances coming from currency crisis. Given that macroeconomic models characterize exchange rates as a way of transmitting of asymmetric shocks, we analyse the role played by the exchange rate as a stabilization tool in open economies through a macroeconomic model describing monetary union. Following Carmona-González and Díaz-Roldán, (Visnik Ekonomika, 2012) we study the consequences of monetary (financial) shocks under alternative monetary agreements (and/or different exchange rate regimes).

We analyse two simple and polar alternative cases: a flexible exchange rate regime and a fixed exchange rate characterized as a monetary union. We show the effects of monetary shocks on the involved economies when there are no restrictions on using the exchange rate and monetary policy as instruments. Next, we examine the consequences of such shocks when there is neither an independent monetary policy, nor an exchange rate policy, and the domestic authorities are constrained by the fiscal discipline imposed by the monetary agreements of a monetary union.

In a two-country model, our results show that an initial common shock can become asymmetric under flexible exchange rates. But, in a monetary union model, the asymmetric effect of appreciation vs. depreciation of nominal exchange rates does not exist. Consequently, a monetary union symmetrizes monetary and external shocks transmitted through the real exchange rate mechanism. 